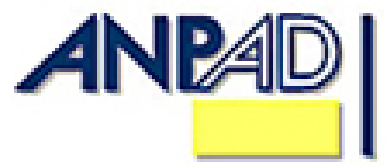

Available online at http://www.anpad.org.br/bar

BAR, Rio de Janeiro, v. 9, Special Issue, art. 6, pp. 95-117, May 2012

(c) EY-NO

\title{
Toward a Subjective Measurement Model for Firm Performance
}

Juliana Bonomi Santos * E-mail address: j.bonomisantos@lancaster.ac.uk Lancaster University Management School Lancaster, UK.

Luiz Artur Ledur Brito E-mail address: luiz.brito@fgv.br Fundação Getúlio Vargas - EAESP/FGV São Paulo, SP, Brazil.

* Corresponding author: Juliana Bonomi Santos

Management Science Department, Lancaster University Management School, Lancaster University, Lancaster, LA1 4YX, UK.

Copyright (C) 2012 Brazilian Administration Review. All rights reserved, including rights for translation. Parts of this work may be quoted without prior knowledge on the condition that the source is identified. 


\begin{abstract}
Firm performance is a relevant construct in strategic management research and frequently used as a dependent variable. Despite this relevance, there is hardly a consensus about its definition, dimensionality and measurement, what limits advances in research and understanding of the concept. This article proposes and tests a measurement model for firm performance, based on subjective indicators. The model is grounded in stakeholder theory and a review of empirical articles. Confirmatory Factor Analyses, using data from 116 Brazilian senior managers, were used to test its fit and psychometric properties. The final model had six firstorder dimensions: profitability, growth, customer satisfaction, employee satisfaction, social performance, and environmental performance. A second-order financial performance construct, influencing growth and profitability, correlated with the first-order intercorrelated, non-financial dimensions. Results suggest dimensions cannot be used interchangeably, since they represent different aspects of firm performance, and corroborate the idea that stakeholders have different demands that need to be managed independently. Researchers and practitioners may use the model to fully treat performance in empirical studies and to understand the impact of strategies on multiple performance facets.
\end{abstract}

Key words: firm performance; confirmatory factor analysis; measurement model; subjective indicators. 


\section{Introduction}

Rigorous construct measurement is critical for the advance of science, particularly when the variables of interest are complex or not observable. Paradoxically, strategic management has been criticized for not giving this topic a high priority (Boyd, Gove, \& Hitt, 2005). The lack of measurement accuracy affects quantitative research quality and masks true relationships (Venkatraman \& Grant, 1986).

This is particularly critical in the case of firm performance, one of the most relevant constructs in the field (Rumelt, Schendel, \& Teece, 1994), and a construct commonly used as the final dependent variable (Richard, Devinney, Yip, \& Johnson, 2009) in various fields (Cho \& Pucik, 2005; Sila \& Ebrahimpuor, 2005; Wiklund \& Shepherd, 2003). Despite its relevance, research into firm performance suffers from problems such as lack of consensus, selection of indicators based on convenience and little consideration of its dimensionality (Combs, Crook, \& Shook, 2005; Crook, Ketchen, Combs, \& Todd, 2008; Richard et al., 2009). Many studies measure firm performance with a single indicator and represent this concept as unidimensional, even while admitting its multidimensionality (Glick, Washburn, \& Miller, 2005). If several dimensions exist, a researcher should choose the dimensions most relevant to his or her research and judge the outcomes of this choice (Richard et al., 2009). Ray, Barney and Muhanna (2004) stress this, warning against the difficulties of testing the resource based theory (RBT) using aggregated measures of performance and suggesting the use of indicators directly connected to the resources under analysis. As such, the strategic management field clearly needs a clearer conceptualization of firm performance, discussions about its dimensions and better measurement efforts. To make a contribution to these issues, we propose and test a multidimensional measurement model of firm performance in this paper.

We grounded our model in the stakeholder theory (Freeman, 1984) and carefully selected a list of indicators to represent the concept of firm performance. We designed the measurement model to allow comparison across firms in the medium-term and tested it in a sample of senior managers and board members of Brazilian companies. We used subjective measures, but not for convenience. These measures are preferable when the focus is on inter-firm comparison (Ketokivi \& Schroeder, 2004), since recording standards of objective indicators vary across firms and industries. They also allow for the assessment of non-financial criteria (Richard et al., 2009). Their use is warranted since they have been proven to be positively associated with objective measures (Dawes, 1999; Forker, Vickery, \& Droge, 1996; Venkatraman \& Ramanujam, 1987; Wall et al., 2004). We identified six different dimensions of performance with good psychometric properties and further explored alternative second order constructs.

Our results may be useful for research and practice. The scales can be used by researchers interested in measuring firm performance across industries with subjective indicators, addressing the Boyd, Gove, and Hitt (2005) call for rigor. They may be particularly useful when other subjective measures are already being collected. The dimensional structure could also help scholars select performance indicators for specific research problems that comprehensively cover the relevant dimensions of performance related to their investigation. The model can contribute to closing the gap between academia and management practice. As Richard, Devinney, Yip, and Johnson (2009, p. 722) put it: "we may not be measuring the performance to which managers are managing". Practitioners may also use this understanding of performance dimensionality to judge the broader impact of their decisions and actions. They too could use the measures to control a company's position in the competitive environment.

This paper is organized as follows. We start the literature review by defining the firm performance domain, differentiating it from a related construct - organizational effectiveness. Next, we develop the stakeholder approach to firm performance and propose seven dimensions of firm performance based on this approach. This section ends with a discussion of alternative ways of combining these seven dimensions in a multidimensional structure of performance. The selection of 
indicators for each dimension and the assessment of validity and reliability follow in the methods and results sections. Finally, we summarize the findings and implications of the mapped structure and suggest further research opportunities.

\section{Literature Review}

\section{Firm performance domain and definitional challenges}

The concept of firm performance needs to be distinguished from the broader construct of organizational effectiveness. Venkatraman and Ramanujan (1986) offered an enlightening figure of three overlapping concentric circles with the largest representing organizational effectiveness. This broadest domain of organizational effectiveness includes the medium circle representing business performance, which includes the inner circle representing financial performance. Organizational effectiveness covers other aspects related to the functioning of the organization as absence of internal strain and faults, engagement in legitimate activities, resource acquisition and accomplishment of stated goals (Cameron, 1986a). Business performance, or firm performance as we refer to it in this article, is a subset of organizational effectiveness that covers operational and financial outcomes.

Although this conceptual proposal of Venkatraman and Ramanujan (1986) is widely referred to by strategic management scholars (Carton \& Hofer; 2006; Richard et al., 2009), the analysis of operationalizations of firm performance used in empirical studies shows a wide variety of approaches covering this domain partially and in an unbalanced way. Combs, Crook, and Shook (2005) analyzed all articles published in the Strategic Management Journal between 1980 and 2004 and identified 238 empirical studies that used 56 different indicators. In most cases, financial performance was used $(82 \%)$ with accounting measures of profitability being the most common choice (52\%). Carton and Hofer (2006) and Richard et al. (2009) reported a similar picture, analyzing different journals in other time periods. Both studies reported a rate of indicator per article of close to one. Our own research, which additionally included Brazilian journals and reported in the methods section of this paper, shows a similar situation.

Another source of confusion is the use of antecedents of performance as performance indicators (Cameron, 1986b). Combs et al. (2005) argue that the operational performance as described by Venkatraman and Ramanujan (1986) is best viewed as an antecedent of financial performance, mediating the effect of resources. The argument has merit and is quite clear in some cases, like production efficiency. But in other aspects, like customer satisfaction, the situation is less clear. While customer satisfaction may be an antecedent of financial performance, is it not a performance outcome, in itself as well? This depends on how one defines firm performance. Defining performance as the satisfaction of stakeholders (Connolly, Conlon, \& Deustch, 1980; Hitt, 1988; Zammuto, 1984) helps to differentiate between antecedents and performance outcomes. In this case, customer satisfaction is clearly also an outcome (using the customer - a stakeholder - perspective) and thus part of firm performance.

Two other aspects must be considered when attempting to define performance: its time frame and its reference point. It is possible to differentiate between past and future performance; past superior performance does not guarantee that it will remain superior in the future (Carneiro, 2005). Another issue related to time is the duration of the interval (short, medium or long term) considered. The reference against which performance is being measured, e.g. the industry average, the results of main competitors, an established target, or past performance (Carneiro, Silva, Rocha, \& Dib, 2007), is also important. Comparisons in relation to targets and past performance indicate the efficiency and evolution of the company. However, they are not suitable for comparing companies from different sizes and industries. Using the average value of the industry or of the main competitors as the baseline indicates companies' competitive position and may be more useful for strategic analyses. 
The definition of firm performance and its measurement continues to challenge scholars due to its complexity. In this paper, we attempt to contribute to this effort by creating and testing a subjective scale of performance that covers the domain of business performance in the words of Venkatraman and Ramanujam (1986). We base our work in the stakeholder theory, which allows distinguishing between performance antecedents and outcomes. It also provides a conceptual structure to define performance indicators and dimensions. We also made choices in relation to time and reference point. Our scale measures past, medium-term performance, and compares the firm to the average competitors in the industry.

\section{A stakeholder approach to firm performance}

The fact that profit and growth are relevant motifs for the existence of a business firm and must be included in any attempt to measure performance is indisputable. The question is: what else is relevant and should be considered as well? In this case, stakeholder theory (Freeman, 1984) can help. Measuring performance under this conceptualization involves identifying the stakeholders and defining the set of performance outcomes that measure their satisfaction (Connolly et al., 1980; Hitt, 1988; Zammuto, 1984).

The stakeholder theory offers a social perspective to the objectives of the firm and, to an extent, conflicts with the economic view of value maximization. Such ontological discussion is outside the scope of this paper; yet the stakeholder theory has found its way into the corporate and academic world. It is possible to see its influence in corporate annual reports. The use of stakeholders' satisfaction as firm performance was also adopted by a large number of different authors (Agle, Mitchell, \& Sonnenfield, 1999; Clarkson, 1995; Kaplan \& Norton, 1992; Richard et al., 2009; Venkatraman \& Ramanujam, 1986; Waddock \& Graves, 1997a). Besides offering a way to decide what performance is in a comprehensive way, the use of this theory allows one to resolve the issue of differentiating between performance antecedents and outcomes. Performance measures assess the satisfaction of at least one group of stakeholders. This conceptualization of firm performance is applicable across different companies, as remarked by Carneiro, Silva, Rocha, and Dib (2007), allowing one to differentiate between high and low performers in the eyes of each stakeholder.

Freeman $(1984$, p. 46) defines a stakeholder as "any group or individual who can affect or is affected by the achievement of the organization's objectives". Taken literally, this definition can include an unmanageable number of constituencies. Clarkson (1995) suggests some important groups. Shareholders and employees, for example, should always be present in any analysis. Other primary stakeholders are suppliers and customers, since they have a direct exchange relationship with the firm. Secondary stakeholders have indirect relationships with the firm, but are clearly affected by its actions, mainly in terms of the social or environmental consequences. Donaldson and Preston (1995) list several classes: governments, trade associations, communities and political groups. In addition, it can be argued that each stakeholder has its own agenda in relation to the company and values a particular set of goals (Fitzgerald \& Storbeck, 2003). Pleasing all parties equally may be an unachievable task, so managers need to prioritize. Mitchell, Agle and Wood (1997) offered a method to identify and judge the salience of the stakeholders relevant to a firm. They used three concepts to do this: the power the stakeholder has over the firm; the legitimacy of the stakeholders' claims; and the urgency of stakeholders' demands. Their final model identifies seven classes of stakeholders depending on combinations of these concepts.

One of the most important conclusions is that stakeholder identification and salience are dependent on the firm in question, on its context and time. Stakeholder selection challenges any measurement and indicates a limitation of the approach; yet some stakeholders are common across firms. We addressed this issue selecting only stakeholders cited in the 2008 annual reports of 15 leading Brazilian companies: shareholders, customers, employees, government and society. Next, we discuss possible measures of stakeholders' satisfaction. 


\section{Possible facets of firm performance}

Superior financial performance is a way to satisfy investors (Chakravarthy, 1986) and can be represented by profitability, growth and market value (Cho \& Pucik, 2005; Venkatraman \& Ramanujam, 1986). These three aspects complement each other. Profitability measures a firm's past ability to generate returns (Glick et al., 2005). Growth demonstrates a firm's past ability to increase its size (Whetten, 1987). Increasing size, even at the same profitability level, will increase its absolute profit and cash generation. Larger size also can bring economies of scale and market power, leading to enhanced future profitability. Market value represents the external assessment and expectation of firms' future performance. It should have a correlation with historical profitability and growth levels, but also incorporate future expectations of market changes and competitive moves.

Customer and employee satisfaction are two further aspects to consider. Customers want companies to provide them with goods and services that match their expectations (Fornell, Johnson, Anderson, Cha, \& Bryant, 1996). To do that, companies must understand their needs, avoid defects and improve the perceived quality and value added by their offerings. Customer satisfaction increases the willingness-to-pay and thus the value created by a company (Barney \& Clark, 2007). Employees' satisfaction is related to investments in human resources practices. This group tends to value clearly defined job descriptions, investment in training, career plans and good bonus policies (Harter, Schmidt, \& Hayes, 2002). The satisfaction of these stakeholders, according to Chakravarthy (1986), translates itself into a firm's ability to attract and retain employees and lower turnover rates.

Indirect stakeholders, like governments and communities, are affected by a number of firm's actions, especially social and environmental ones. Social and environmental performance can be considered a way to satisfy communities (Chakravarthy, 1986) and governments (Waddock \& Graves 1997a). Some activities associated with the satisfaction of these groups are safe environmental practices, increased product quality and safety, ethical advertising, minority employment and development of social projects (Agle et al., 1999; Johnson \& Greening, 1999; Waddock \& Graves, 1997a, 1997b).

Acknowledging the limitations discussed before, conceptualization of firm performance, as based on satisfying the stakeholders, can be thought of as having at least seven facets: growth, profitability, market value, customer satisfaction, employee satisfaction, social performance and environmental performance.

\section{Dimensional models for firm performance}

Constructs can be unidimensional or multidimensional. Figure 1 presents two models to elucidate these possible representations of firm performance (only a few dimensions were used for simplicity purpose). 


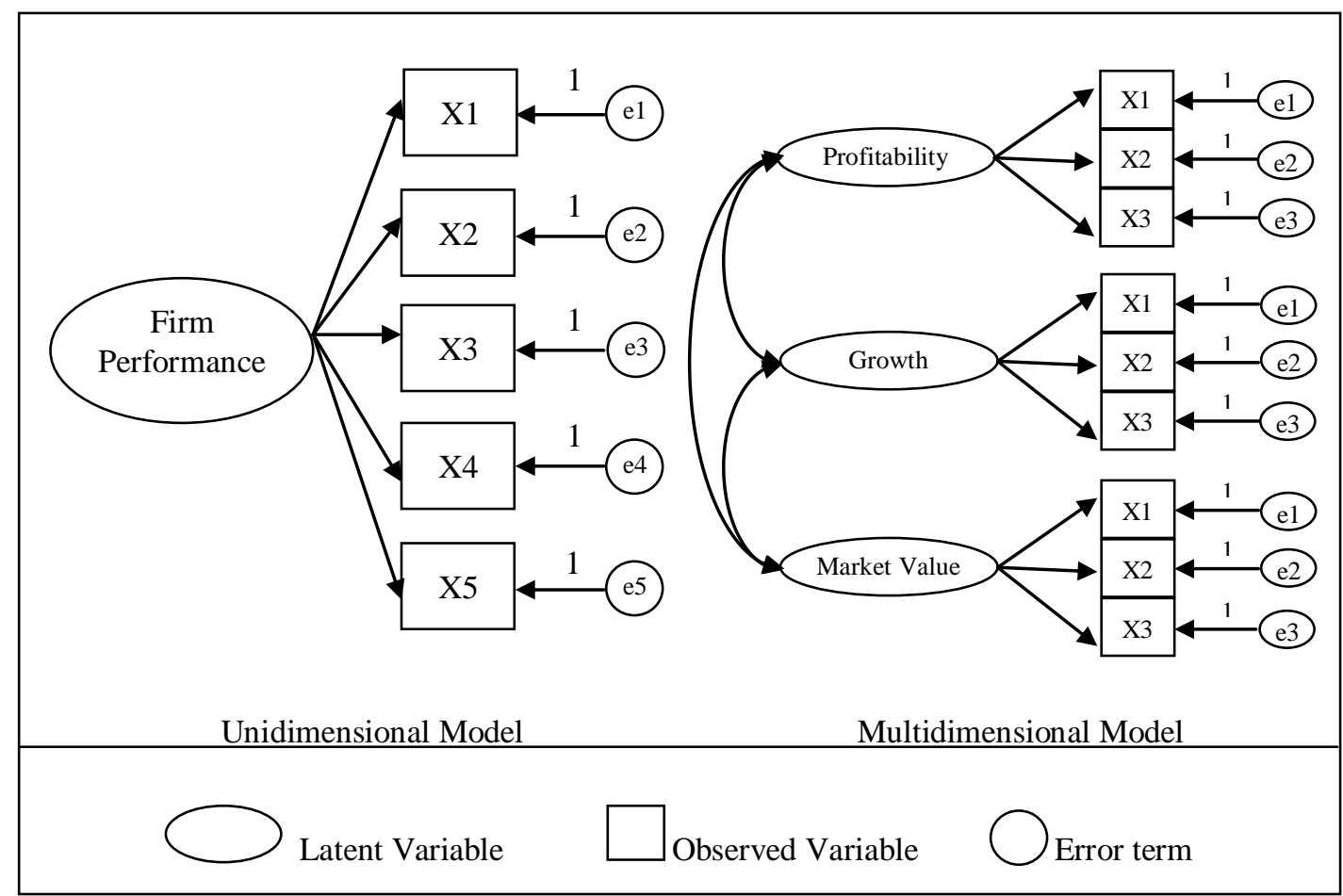

Figure 1. Unidimensional and Multidimensional Representation.

Unidimensionality, the left-side model, implies that all the indicators illustrate the performance of the firm in an almost interchangeable way. Indicators in this case should be highly correlated. Multidimensionality suggests that each dimension symbolizes one facet of the overall result of the company, and is represented by a particular group of indicators. Observed indicators of the same domain should cluster together in one dimension, having higher correlations among themselves than with indicators of different dimensions. Theoretical perspectives and empirical studies point toward multidimensionality, with multiple dimensions that make up the complex and complete notion of performance.

Based on the stakeholder theory, unidimensionality would mean that all the stakeholders have similar demands and needs, but this is unlikely (Simerly \& Li, 2000). Unidimensionality would be a simplistic representation for such a complex construct (Cameron, 1986b; Chakravarthy, 1986; Combs et al., 2005; Murphy, Trailer, \& Hill, 1996; Seashore \& Yuchtman, 1967; Steers, 1975). Additionally, indicators used to measure different aspects of performance have already been submitted to factor analysis by several authors who found multidimensional structures (Baum \& Wally, 2003; Cho \& Pucik, 2005; Combs et al., 2005; Fornell et al., 1996; Johnson \& Greening, 1999; Rowe \& Morrow, 1999; Sila \& Ebrahimpour, 2005; Sila, 2007; Silverman, Nickerson, \& Freeman, 1997).

A complete analysis of multidimensional constructs needs to explore the existence of secondorder structures that can group first-order dimensions. Glick, Washburn, and Miller (2005) suggest that firm performance could be conceptually represented by one second-order construct reflecting itself on its first-order dimensions (Figure 2, model on the left). These first-order dimensions, although different from each other, would be symptoms of a more general, higher order: performance (Glick et al., 2005). This would require all dimensions to have positive and strong correlations. The Venkatraman and Ramanujam (1986) conceptual model suggests an alternative representation, in which performance would have two second-order dimensions: the financial one, represented by profitability, growth and market value; and the operational domain, that includes non-financial competitive aspects, like customer satisfaction, quality, innovation, employee satisfaction and reputation (Figure 2, model on the right). We, however, prefer the name strategic performance to operational performance. 


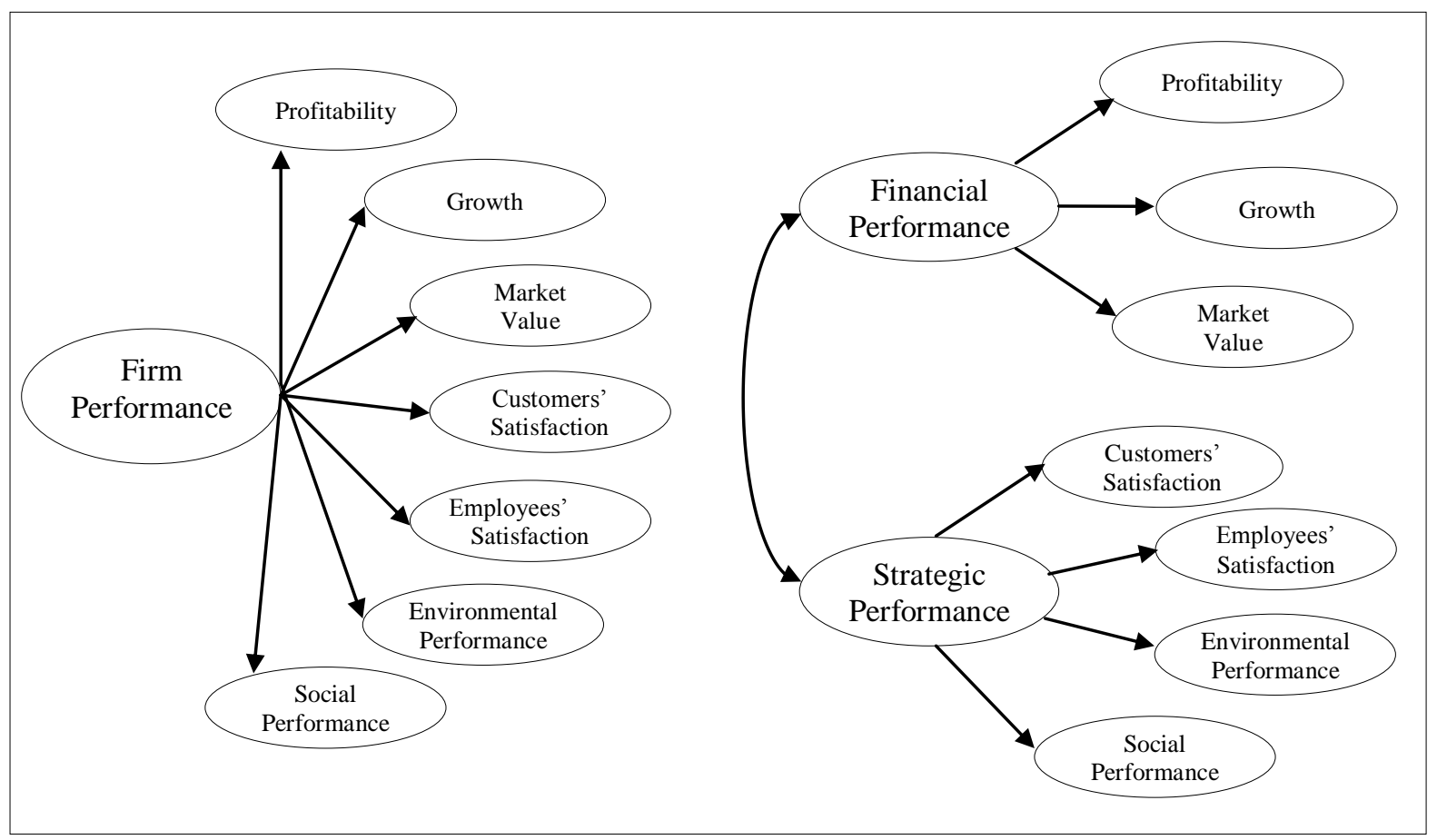

Figure 2. Second Order Models.

Rowe and Morrow (1999) found evidence of a financial second-order construct composed of financial reputation, market value and profitability. Our review failed to find studies that tested second-order non-financial constructs. As second order constructs are always multidimensional models defined according to theoretical assumptions or underlying correlations, several alternative second-order structures are possible with different groupings of the first-order dimensions. In this paper, we test these two theoretical models and proceed in an exploratory way to identify other grouping alternatives.

\section{Methods}

\section{Operational definition of constructs}

To identify potential indicators for each presumed performance aspect (growth, profitability, market value, customer and employees' satisfaction, and social and environmental performance) we investigated related academic journals and Brazilian companies' annual reports. We selected ten journals (Academy of Management Journal, Academy of Management Review, Administrative Science Quarterly, Strategic Management Journal, International Journal of Operations \& Production Management, Journal of Operations Management, Production and Operations Management, Revista de Administração de Empresas, Revista de Administração Contemporânea, Revista de Administração da Universidade de São Paulo) and identified 177 empirical articles from 1995 to 2006 that used some form of performance operationalization. Four of these journals are from the strategic management field where firm performance is frequently the dependent variable of empirical studies. Three journals are from the operations management field that has a line of research about business performance measurement (Neely, 2007). The remaining three journals are leading Brazilian academic journals. These articles used 122 different indicators of performance. We chose the 65 indicators used by at least two papers.

To ensure a selection of indicators consistent with the Brazilian environment, we examined the 2008 annual reports of 15 leading Brazilian companies and created another list of performance indicators. After comparing these two sets of indicators, we ended up with 35 performance indicators 
used at least twice in the academic papers and mentioned by at least one Brazilian leading company. We added two additional indicators present in several annual reports and not investigated by the empirical studies, reaching 37 performance indicators (Table 1) to represent the seven presumed performance constructs.

Table 1

Performance Dimensions and Indicators Selected

\begin{tabular}{ll}
\hline \multicolumn{1}{c}{ Dimensions } & \multicolumn{1}{c}{ Selected Indicators } \\
\hline Profitability & $\begin{array}{l}\text { Return on Assets, EBTIDA margin, Return on investment, Net income/Revenues, } \\
\text { Return on equity, Economic value added }\end{array}$ \\
Market Value & $\begin{array}{l}\text { Earnings per share, Stock price improvement, Dividend yield, Stock price volatility, } \\
\text { Market value added (market value / equity), Tobin's q (market value / replacement } \\
\text { value of assets) }\end{array}$ \\
Growth & $\begin{array}{l}\text { Market-share growth, Asset growth, Net revenue growth, Net income growth, } \\
\text { Number of employees growth }\end{array}$ \\
Employee Satisfaction & $\begin{array}{l}\text { Turn-over, Investments in employees development and training, Wages and rewards } \\
\text { policies, Career plans, Organizational climate, General employees' satisfaction }\end{array}$ \\
Customer Satisfaction & $\begin{array}{l}\text { Mix of products and services, Number of complaints, Repurchase rate, New } \\
\text { customer retention, General customers' satisfaction, Number of new } \\
\text { products/services launched }\end{array}$ \\
Environmental & $\begin{array}{l}\text { Number of projects to improve / recover the environment, Level of pollutants } \\
\text { emission, Use of recyclable materials, Recycling level and reuse of residuals, } \\
\text { Performance }\end{array}$ \\
Number of environmental lawsuits \\
Social Performance
\end{tabular}

These indicators were items of a questionnaire asking respondents to judge their company's performance as compared to the competition for each indicator. Depending on the context, performance measurement may require indicators that are difficult to access (Ketokivi \& Schroeder, 2004). The same authors suggest that objective performance measures are less convenient for nonfinancial performance measurement and for inter-firm comparison when firms have different ways of registering information. In these cases, researchers (Forker et al., 1996; Slater \& Olson, 2000; Wiklund \& Shepherd, 2003) should adopt subjective measures and request informants to compare performance criteria in relation to a benchmark. The critique over subjective performance indicators is that they depend on human cognition and knowledge. Resultant data may be over- or underestimated, may suffer from halo effects or may just be a guess (Ketokivi \& Schroeder, 2004; Richard et al., 2009).

Nevertheless, subjective and objective performance indicators proved to be positively correlated (Dawes, 1999; Dess \& Robinson, 1984; Forker et al., 1996; Venkatraman \& Ramanujam, 1987; Wall et al., 2004). These studies tested mainly financial measures and found statistically significant correlations $(\mathrm{p}<0.05)$ ranging from 0.44 to 0.69 . Correlations are not particularly high, but they are significant and positive, indicating that subjective and objective measures point in the same direction. Additionally, Venkatraman and Ramanujam (1987) found strong convergence between the two types of measures using a confirmatory factor analysis. When objective and subjective performance measures were correlated to other constructs, similar results in terms of significance and magnitude were found for both types of measure (Wall et al., 2004).

These results suggest subjective measures can be used to assess firm performance and probably lead to convergent results of different magnitudes. In this case, Ketokivi and Schroeder (2004) 
advocate in favor of practices intended to improve validity and reliability, such as collecting data from multiple respondents, and using different methods and indicators.

\section{Data collection instrument}

Two sections composed the questionnaire. Part one contained one question about respondents' position within the organization and three questions about firms' profile: size in terms of annual revenue, sector responsible for the main stream of revenue, and experience within the sector. These questions were designed to estimate sample demographics and evaluate eventual sample bias (presented later). The second section was subdivided into seven topics, each named after one of the seven proposed aspects of firm performance. The topic was followed by the question: How was the firm performance, in the last 3 years, when compared to the average competitors of the sector in terms of. Underneath, we displayed the respective set of indicators and a five-point scale ranging from below average to above average. We did not ask for objective performance measures due to their sensitive nature.

A similar subjective question to assess firm performance was used in the work of Wiklund and Shepherd (2003) and produced valid and reliable results. We adopted this question for two reasons. Comparing the firm to the industry's average allowed controlling for different economic activities in the sample (Dawes, 1999). Other researchers also relied on respondents to minimize the sector influence on the data set (Forker et al., 1996; Slater \& Olson, 2000). Additionally, the use of a period of time (three years) instead of a single year smooths eventual fluctuations in the results of the companies (Kim, Hoskisson, Won, 2004).

The first version of the questionnaire was examined by experts (financial analysts, professors, and doctoral students of a leading Brazilian business school) to judge face validity, questionnaire physical appeal, word ordering, time demand, and clearness. After adjustments, we performed a pretest with 25 subjects for an initial assessment of reliability and validity, introducing few modifications. The final instrument was later used in the field research.

\section{Sample and data collection}

Our target population was high-level executives within Brazilian organizations, such as board members, presidents, vice-presidents, and directors, as suggested by Venkatraman and Ramanujan (1987). These high-level executives were presumed to know organizational performance goals and to be responsible for defining or helping to define organizations' strategies. They certainly do not fully represent all stakeholders. Yet they should be in a position to make a balanced judgment of the different demands of each stakeholder group.

Respondents came from two databases. The first one was from the Brazilian Institute of Corporate Governance and the other was a selected stratum of the alumni of a leading business school. Our final database had 2443 potential respondents. The data collection instrument was sent to all and the initial response rate was 3\% (74). After two weeks, e-mails were sent to respondents that had not answered and 42 people filled the questionnaire in this time. Our final sample had 116 respondents and the response rate was $4.7 \%$. The low response rate and the database composition are threats to generalizability and the final sample is better treated as a convenience sample (Krosnick, 1999). Data was collected on-line and I.P. control was used to avoid more than one respondent per firm. To check for differences between the two databases and response waves, we conducted a two-population means test for independent samples for each variable and found no evidence of bias $(\mathrm{P}<5 \%)$.

\section{Data treatment and analysis}

We eliminated four questionnaires with less than $40 \%$ of answered questions and dropped one questionnaire with standard deviation within answers below 0.3. In our final analyses, we used 111 respondents. Our sample was fairly heterogeneous (Table 2), with small, medium and large companies 
from different industries and various levels of experience. As expected, all respondents had a high decision-making level within the company. We further analyzed the frequency distribution and descriptive statistics for all variables and concluded that the distributions were close to the normal and identified no relevant outliers.

Table 2

Firm and Respondent Profiles

Indicators and Results

1) Which of the following options better represents your position in the company
a) Board Member
b) President
c) Vice-president
d) Director
e) Partner
f) Senior-manager

2) Firm Size: Annual net revenue of the firm

a) Up to $\mathrm{R} \$ 50$ millions

b) $\mathrm{R} \$ 50$ millions to $\mathrm{R} \$ 100$ millions

c) $\mathrm{R} \$ 100$ millions to $\mathrm{R} \$ 500$ millions

d) $\mathrm{R} \$ 500$ millions to $\mathrm{R} \$ 1$ billion

e) $\mathrm{R} \$ 1$ billion to $\mathrm{R} \$ 6$ billions

f) More than R\$6 billions

$\begin{array}{cc}\begin{array}{c}\text { Number of } \\ \text { Respondents }\end{array} & \begin{array}{c}\text { Percent of } \\ \text { Total }\end{array} \\ 26 & 23.5 \\ 25 & 22.5 \\ 6 & 5.4 \\ 47 & 42.3 \\ 6 & 5.4 \\ 1 & 0.9 \\ \text { Number of } & \text { Percent of } \\ \text { Firms } & \text { Total } \\ 35 & 31.6 \\ 13 & 11.7 \\ 32 & 28.8 \\ 9 & 8.1 \\ 11 & 9.9 \\ 11 & 9.9\end{array}$

3) Firm Sector: Economic classification of the firm. If the firms has more than one classification, please consider the one responsible for the greater amount of net revenues

Agriculture, Forestry, Fishing and Hunting

Financial Activities and Insurance

\begin{tabular}{cc}
$\begin{array}{c}\text { Number of } \\
\text { Firms }\end{array}$ & $\begin{array}{c}\text { Percent } \\
\text { of Total }\end{array}$ \\
2 & 1.8 \\
6 & 5.4 \\
9 & 8.1 \\
21 & 18.9 \\
9 & 8.1 \\
11 & 9.1 \\
9 & 8.1 \\
6 & 5.4 \\
32 & 28.8 \\
7 & 6.3 \\
\hline
\end{tabular}

Automation, Technology, Capital Goods

Consumer Goods

Intermediary Goods

Commerce

Construction

Information and Communication Technology

Other Services

Continues 
Table 2 (continued)

\begin{tabular}{|c|c|c|}
\hline \multicolumn{3}{|l|}{ Indicators and Results } \\
\hline $\begin{array}{l}\text { 4) Firm Experience: For how many years the firm operates in this } \\
\text { sector }\end{array}$ & $\begin{array}{l}\text { Number of } \\
\text { Firms }\end{array}$ & $\begin{array}{l}\text { Percent of } \\
\text { Total }\end{array}$ \\
\hline a) 0 to 5 years & 5 & 4.5 \\
\hline b) 5 to 10 years & 14 & 12.6 \\
\hline c) 10 to 40 years & 42 & 37.9 \\
\hline d) 40 to 70 years & 34 & 30.6 \\
\hline e) 70 to 100 years & 11 & 9.9 \\
\hline f) More than 100 years & 5 & 4.5 \\
\hline
\end{tabular}

Note. Sample size of 111.

Next we evaluated the reliability of the measures. Given our limitation of subjects, we used a common method of internal consistency: the Cronbach's alpha (Pedhazur \& Schelkin, 1991). Six of the seven dimensions presented alphas well above 0.8 ; only the social performance dimension scored lower, at 0.67 . We associated this issue with the small number of indicators used to measure social performance, since the alpha is a function of the number of items in the scale (Netemeyer, Bearden, \& Sharma, 2003). We kept social performance items because of their nomological validity. Unfortunately, we were not able to compare our data to objective performance measures to check for alternative-forms reliability. Given the sensitive nature of performance data, we assured respondent data confidentiality by not asking their personal data and by not requiring company identification.

After initial data treatment, we used Confirmatory Factor Analysis to test the dimensional structure of performance using AMOS 16 software. The number of missing data for the market value items forced us to eliminate this dimension. Since we used a discrete five-point scale, we compared the polychoric correlations to the traditional Spearman correlations, but no significant differences were found. Close to normal distributions and a sample size of 111 observations allowed the use of maximum likelihood estimation, recommended for samples between 100 and 150 cases (Hair, Anderson, Tatham, \& Black, 2005), and small deviations from normality (Shah \& Goldstein, 2006).

The first step of the analysis was to confirm the multidimensionality of the firm performance construct. We compared a multidimensional model with six first-order freely correlated dimensions (growth, profitability, customer satisfaction, employee satisfaction, social performance and environmental performance) with a unidimensional model having all items loading into a single construct. In a second step, we explored alternatives of second-order constructs to understand further the structure of the performance construct. Two models were proposed based on the literature review (represented in Figure 2) and an additional second-order model emerged during the data analysis. These models are explained later.

Models were assessed in terms of fit, validity and reliability. Model fit was evaluated using several indexes. The chi-square test indicates whether the difference between the data correlation matrix and the implied calculated matrix is significant. If the difference is significant one cannot say the model fits the data and, therefore, it should be rejected (Mueller, 1996). This test is sensitive to the sample size and to the number of variables in the model (Hair et al., 2005) sometimes leading to an inappropriate model rejection. Other indexes need to be considered. The Root Mean Square Error of Approximation (RMSEA) is a relevant overall fit index. RMSEA should be below 0.08 and preferably below 0.05 (Kline, 2005). Incremental fit was assessed with the Tucker-Lewis index (TLI), the Comparative Fit Index (CFI), and the Incremental Fit Index (IFI), given we used less than 250 observations (Shah \& Goldstein, 2006). Values above 0.90 indicate a good fit (Hair et al., 2005). 
Convergent validity was judged based on the factors loading and on the extracted variances. High significant loading and extracted variances above 50\% indicate that the measurement error is less than the explained variance suggesting convergent validity (Shook, Ketchen, Hult, \& Kacmar, 2004). Discriminant validity was assessed comparing the squared interconstruct correlations (SIC) to the extracted variance. SIC values indicate the variance shared by two constructs. If they are higher than the extracted variance, it is highly likely that only one construct exists (Fornell \& Larcker, 1981). Composite reliability was calculated in addition to the Cronbach's alpha, because the number of variables used influence this reliability index less (Pedhazur \& Schmelkin, 1991). Composite reliability should be at least 0.7 (Hair et al., 2005). Finally, we tested for the significance in the models' chi-square differences given the different degrees of freedom. In case of statistically significant differences, models with lower chi-squares are preferred (Chen, Paulrauj, \& Lado, 2004).

\section{Results and Discussion}

\section{Multidimensionality assessment}

The unidimensional first-order model had a poor fit: chi-square was significant $1302(\mathrm{p}<0.001)$, RMSEA was 0.175 , well above the limit, and TFI, CFI, and IFI were $0.48,0.56$, and 0.57 , far from the 0.90 limit. The normed chi-square (chi-squared divided by the degrees of freedom) was 4.35 when a value of less than 3 is desirable. The multidimensional model with six first-order dimensions had a fair fit. The chi-square test was still significant, $458(\mathrm{p}<0.001)$, but the other indexes suggest a reasonable fit. The normed chi-square was 1.62, RMSEA was 0.07 and CFI, TLI, and IFI were all above 0.9. Results are shown in Table 3.

Table 3

\section{Fit Indexes for First-Order Models}

\begin{tabular}{lccc}
\hline \multicolumn{1}{c}{ Indexes } & Unidimensional & Multidimensional & Recommended Values \\
\hline Chi-Square & $1302(\mathrm{p}<0.01)$ & $458(\mathrm{p}<0.01)$ & $\mathrm{p}>0,05$ (not significant) \\
Degrees of Freedom & 299 & 285 & - \\
RMSEA & 0.18 & 0.07 & $<0.08$ \\
CFI & 0.56 & 0.92 & $>0.9$ \\
TLI & 0.49 & 0.91 & $>0.9$ \\
IFI & 0.57 & 0.93 & $>0.9$ \\
Normed Chi-Squared & 4.35 & 1.62 & $<2.0$ \\
\hline
\end{tabular}

Note. Recommended values based on Kline, R. B. (2005). Principles and practice of structural equation modeling (2nd ed., pp. 137 and 139-141). New York: Guilford Press.

Since both models can be considered nested, it is possible to test the significance of their difference with the chi-square test. The chi-square difference was 844 and the difference in degrees of freedom was 15 . The chi-square difference was statistically significant $(\mathrm{p}<0.001)$, and the lower chisquare value confirmed the superiority of the multidimensional model. Validity and reliability analyses also indicate the multidimensional model as preferred. The unidimensional model showed poor convergent validity. Items related to social and environmental performance had loads not statistically significant ( $>0.10)$ and the extracted variance was only $34.54 \%$, explaining just a third of the variability. The multidimensional model proved to be valid and reliable (table 4). All loads were positive, higher than 0.55 and statistically different from zero $(\mathrm{p}<0.001)$ and the variance extracted by 
each of the six constructs was above 50\%. Only social performance had a composite reliability of 0.69 , close to the reference of 0.70 (Hair et al., 2005). All other dimensions had values above 0.85 .

Table 4

\section{Standardized Loads and Error Terms for the Multidimensional Model}

\begin{tabular}{|c|c|c|c|c|c|c|}
\hline Construct & $\begin{array}{c}\text { Comp. } \\
\text { Reliabi } \\
\text { lity }\end{array}$ & A.V.E & Items $^{a}$ & $\begin{array}{l}\text { Stand. } \\
\text { Factor } \\
\text { Loads }\end{array}$ & $\begin{array}{l}\text { Error } \\
\text { Term }^{b}\end{array}$ & $\begin{array}{l}\text { Critical } \\
\text { Ratiob,c }\end{array}$ \\
\hline \multirow[t]{4}{*}{ Growth } & 0.9 & 0.70 & Market Share Growth & 0.79 & - & - \\
\hline & & & Asset Growth & 0.79 & 0.11 & 9.05 \\
\hline & & & Revenue Growth & 0.86 & 0.11 & 10.06 \\
\hline & & & Net Profit Growth & 0.91 & 0.12 & 10.75 \\
\hline \multirow[t]{6}{*}{ Profitability } & 0.97 & 0.84 & EVA & 0.91 & - & - \\
\hline & & & ROA & 0.91 & 0.06 & 15.68 \\
\hline & & & EBTIDA Margin & 0.91 & 0.06 & 15.44 \\
\hline & & & ROI & 0.96 & 0.05 & 18.74 \\
\hline & & & ROS & 0.88 & 0.06 & 14.25 \\
\hline & & & ROE & 0.94 & 0.06 & 17.48 \\
\hline \multirow{4}{*}{$\begin{array}{l}\text { Environmental } \\
\text { Performance }\end{array}$} & 0.93 & 0.75 & Environmental Projects & 0.86 & - & - \\
\hline & & & Recycling & 0.88 & - & - \\
\hline & & & Use of Recyclables & 0.91 & 0.07 & 15.29 \\
\hline & & & Pollutants Emissions & 0.81 & 0.08 & 11.55 \\
\hline \multirow{2}{*}{$\begin{array}{l}\text { Social } \\
\text { Performance }\end{array}$} & 0.67 & 0.54 & Minority Employment & 0.56 & - & - \\
\hline & & & Social Projects & 0.88 & 0.39 & 4.17 \\
\hline \multirow{5}{*}{$\begin{array}{l}\text { Customer } \\
\text { Satisfaction }\end{array}$} & 0.85 & 0.53 & Value Added & 0.70 & - & - \\
\hline & & & Cust. Retention & 0.77 & 0.18 & 7.16 \\
\hline & & & Cust. Loyalty & 0.77 & 0.17 & 7.17 \\
\hline & & & No. Complains & 0.57 & 0.18 & 5.40 \\
\hline & & & $\begin{array}{l}\text { Overall Customer } \\
\text { Satisfaction }\end{array}$ & 0.80 & 0.14 & 7.36 \\
\hline \multirow{5}{*}{$\begin{array}{l}\text { Employee } \\
\text { Satisfaction }\end{array}$} & 0.88 & 0.59 & Investment in Employees & 0.72 & - & - \\
\hline & & & Payment of Benefits & 0.70 & 0.11 & 6.97 \\
\hline & & & Career Opportunities & 0.79 & 0.10 & 7.78 \\
\hline & & & Organizational Climate & 0.77 & 0.11 & 7.60 \\
\hline & & & $\begin{array}{l}\text { Overall Employee } \\
\text { Satisfaction }\end{array}$ & 0.86 & 0.10 & 8.46 \\
\hline
\end{tabular}

Note. ${ }^{\text {a }}$ Indicators eliminated due to low reliability: turnover, number of employees growth, number of environmental lawsuits, number of new products/services launched, number of lawsuits filed by employees, customers and regulatory agencies. ${ }^{\mathrm{b}}$ “_." indicates variables loadings fixed to the value of one. ${ }^{c}$ Estimates of all indicators significant at the level $\mathrm{p}<0.001$.

The multidimensional model also presented discriminant validity. The six dimensions presented squared interconstruct correlations (SIC) lower than the extracted variance (Fornell \& Larcker, 1981). 
Table 5 shows the SIC values on the upper right side, the extracted variances on the main diagonal and correlations between constructs on the bottom left side.

Table 5

Correlation and Squared Interconstruct Correlations Matrix

\begin{tabular}{lcccccc}
\hline \multicolumn{1}{c}{ Constructs } & $\mathbf{1}$ & $\mathbf{2}$ & $\mathbf{3}$ & $\mathbf{4}$ & $\mathbf{5}$ & $\mathbf{6}$ \\
\hline 1. Growth & $\mathbf{0 . 7 0}$ & 0.66 & 0.34 & 0.15 & 0.00 & 0.01 \\
2. Profitability & $0.81^{* *}$ & $\mathbf{0 . 8 4}$ & 0.36 & 0.22 & 0.02 & 0.02 \\
3. Customer Satisfaction & $0.58^{* *}$ & $0.60^{* *}$ & $\mathbf{0 . 5 3}$ & 0.28 & 0.04 & 0.02 \\
4. Employee Satisfaction & $0.39^{* *}$ & $0.47^{* *}$ & $0.53^{* *}$ & $\mathbf{0 . 5 9}$ & 0.34 & 0.31 \\
5. Social Performance & 0.00 & 0.13 & 0.21 & $0.58^{*}$ & $\mathbf{0 . 5 4}$ & 0.30 \\
6. Environmental Performance & 0.06 & 0.13 & 0.14 & $0.56^{* *}$ & $0.55^{* *}$ & $\mathbf{0 . 7 5}$ \\
\hline
\end{tabular}

Note. for $\mathrm{N}=111, * * \mathrm{p}<0.001 ; * \mathrm{p}<0.050$.

After confirming that the multidimensional model fits the data better, we evaluated the correlations between the six performance dimensions (Table 5). The strongest correlation was between growth and profitability, suggesting the existence of a second-order construct of financial performance. Social and environmental performance showed weak correlations with growth, profitability, and customer satisfaction, but moderate and significant correlation with employee satisfaction. Given this pattern of correlations, the existence of second-order constructs is possible and is explored in the next section.

The inadequacy of the unidimensional model has serious implications for research and practice. This seriousness is augmented by the fact that 8 of the 15 correlations between dimensions were below 0.5 indicating they truly cover different aspects of performance. These results join, extend and support findings of previous studies. Research design needs to consider multidimensionality. For example, if one intends to test the relationship between specific resources and performance, the choice of performance dimensions is critical. The multidimensional model suggests a structure of how to approach this disaggregation. Practitioners also need to be aware of these multiple dimensions. Some of their actions targeted at specific performance outputs need to be judged on how they might affect others. Since the model was based on stakeholder theory, this supports the argument of balancing the different stakeholders' demands (Mitchell, Agle, \& Wood, 1997).

\section{Second-order models}

We started this step of the analysis by adopting the multidimensional first-order model as our baseline and comparing the second-order models to it. The first of the second-order models, Model A, has only one second-order dimension. This model suggests the existence of an overarching secondorder construct that represents firm performance and influences growth, profitability, customer satisfaction, employee satisfaction, and social and environmental performance. The second model, Model B, has two second-order dimensions: financial and strategic performance. Financial performance influences growth and profitability while strategic performance is an overarching performance conceptualization covering all non-financial aspects. After testing these two models we continued in an exploratory way to identify alternatives for grouping the six constructs. This effort led us to propose model $\mathrm{C}$.

The statistical testing of second-order constructs followed Brown's (2006) recommendations. The first step is to have a good first-order model. Second-order models can never present a better fit than first-order models since they are more restrictive, given that constructs can freely correlate in the first-order model. The inclusion of a second-order construct restrains this correlation that now must be 
caused by a common second-order construct. When the difference between a second-order model and a first-order is not statistically significant, the existence of the second-order alternative cannot be rejected statistically. This test can be done with the chi-square difference because models are nested. The second-order model should also be analyzed in relation to convergent and discriminant validity. The extracted variance must be above 50\% and the loads on the first-order dimensions must be high and statistically significant. The conceptual justification for the second-order model combined with its non-rejection allows us to accept it.

Model A, with only one second-order common dimension, had a poor fit with a RMSEA of 0.086 and CFI, TFI, and IFI indexes below 0.9. The extracted variance by the second-order factor was only $39 \%$ and no first-order construct presented a statistically significant loading. The chi-square difference test when comparing this model with the multidimensional first-order model was highly significant $(\mathrm{p}<0.001)$. We could confidently reject model A. Model B had a marginal fit with RMSEA of 0.080 and CFI, TFI, and IFI indexes close to 0.9. The strategic performance, second-order construct, had low, although statistically significant $(\mathrm{p}<0.001)$, loads and extracted variance was $48 \%$. The second-order, financial performance construct had significant loads on growth (0.81) and profitability (0.99) and was able to extract $81 \%$ of the variance from these factors. Reliability was also high (0.9). Correlation between the two second-order constructs was $0.47(\mathrm{p}<0.05)$. The chi-square difference test, however, was highly significant $(p<0.001)$ indicating that Model B was significantly inferior to the first-order model with six dimensions freely correlated. Given these considerations we also reject Model B. Results are in Table 6.

In an exploratory manner, we tried to identify alternative second-order constructs. We could not reach any viable alternative beyond the second-order financial performance, which combined the firstorder dimensions of profitability and growth. So our final proposed measurement model of firm performance, Model C, has a second-order dimension for financial performance and maintains the customer satisfaction, employee satisfaction, social and environmental performance dimensions as independent, freely correlated constructs.

Table 6

Fit Indexes for Second-Order Models

\begin{tabular}{lccccc}
\hline Fit Indexes & $\begin{array}{c}\text { First Order } \\
\text { Model Baseline }\end{array}$ & Model A & Model B & Model C & $\begin{array}{c}\text { Recommended } \\
\text { Values }\end{array}$ \\
\hline Chi-Square & 458 & 534 & 497 & 460 & $\mathrm{p}>0,05$ \\
Degrees of Freedom & 285 & 294 & 293 & 288 & - \\
Chi-Square & & 76 & 39 & 2 & $\mathrm{p}>0,05$ \\
Dif. to Baseline & - & $(\mathrm{P}<0.001)$ & $(\mathrm{P}<0.001)$ & $(\mathrm{P}<0.001)$ & $(\mathrm{P}<0.001)$ \\
RMSEA & 0.074 & 0.086 & $(\mathrm{P}<0.001)$ & $(\mathrm{P}=0.57)$ & $($ not signif. $)$ \\
CFI & 0.92 & 0.89 & 0.080 & 0.074 & $<0.080$ \\
TLI & 0.91 & 0.87 & 0.89 & 0.93 & $>0.90$ \\
IFI & 0.93 & 0.89 & 0.91 & 0.91 & $>0.90$ \\
Normed Chi-Squared & 1.62 & 1.81 & 1.69 & 0.93 & $>0.90$ \\
\hline
\end{tabular}

Note. Recommended values based on Kline, R. B. (2005). Principles and practice of structural equation modeling (2nd ed., pp. 137 and 139-141). New York: Guilford Press.

Model C (Figure 3) had a good fit and the chi-square test did not show a significant difference from the baseline model (Table 6). It was also valid and reliable. Composite reliability of the secondorder construct was high $(0.9)$, loads were all statistically significant $(\mathrm{p}<0.001)$, and extracted variance 
was $81 \%$. Squared interconstruct correlations were lower than extracted variances, indicating discriminant validity between the second- and first-order constructs. Composite reliabilities of firstorder dimensions were above 0.7. Correlations between dimensions above 0.15 were significant; overall they were moderate and positive.

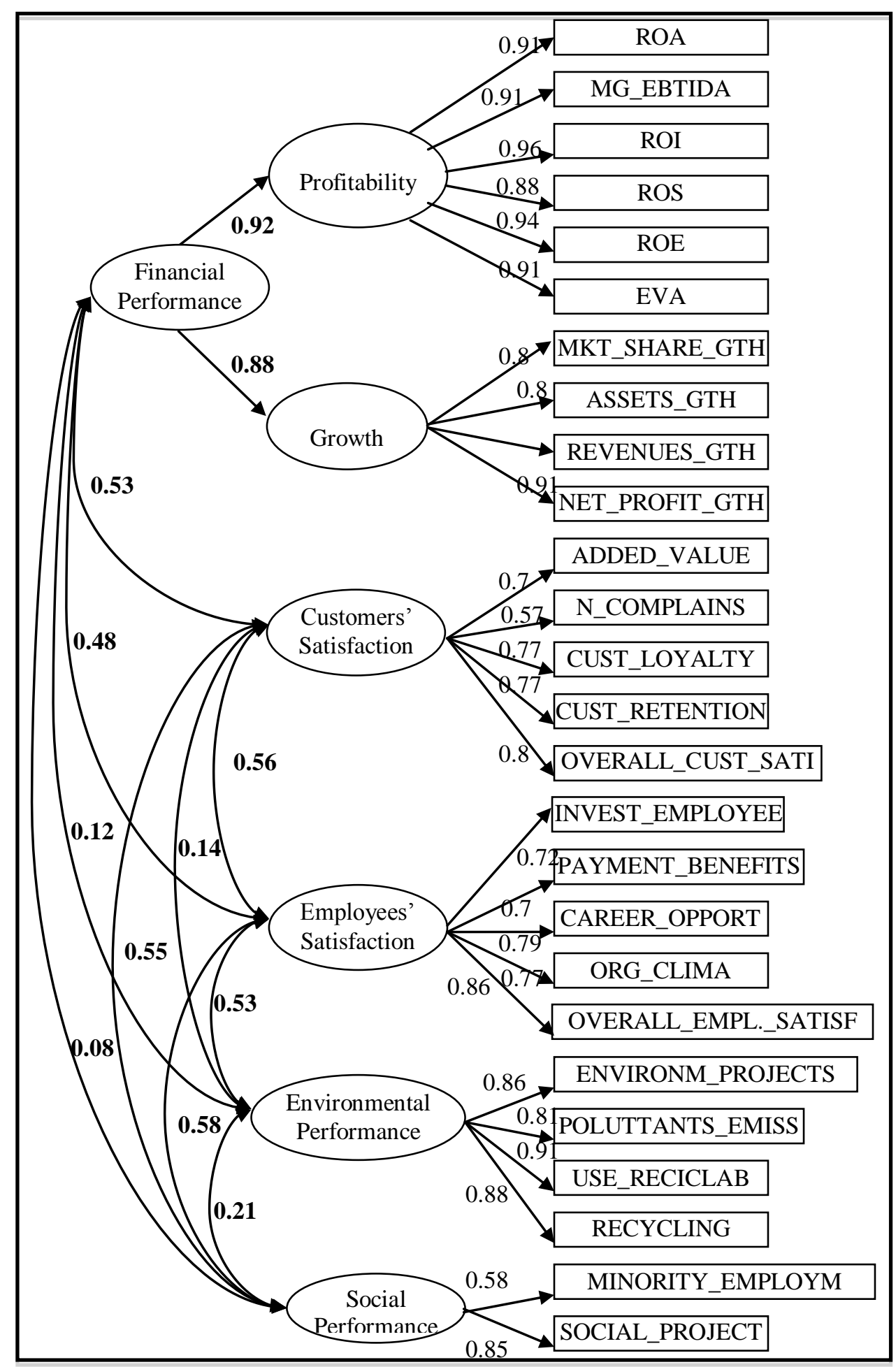

Figure 3. Model C: One Second Order Construct, Financial Performance, and Four Independent First Order Dimensions with Free Correlations.

Our results do not support the notion of a general second-order performance construct that manifests itself in first-order dimensions (poor fit of model A), as suggested by Glick et al. (2005). 
The lack of statistical support for Model B and the good fit of model C (Figure 3) offer a deeper insight into the much cited Venkatraman and Ramanujan (1986) conceptual model of a core financial performance domain, within a broader domain of operational performance. Our results corroborate the existence of the financial performance domain. Yet, the absence of a non-financial second-order construct indicates the operational performance domain may not exist. Non-financial aspects are actually independent and do not vary in a similar ways. These findings reinforce the multidimensionality argument explored earlier.

\section{Conclusions}

Despite its relevance to strategic management, firm performance suffers from limited conceptualization, selection of indicators based on convenience, and no proper consideration of its dimensionality. This paper makes a contribution to the joint effort of finding proper conceptualizations of performance and related measurements. Two major contributions can be identified: one is instrumental, another conceptual. The instrumental contribution relates to the scale itself, which can be used in other empirical studies. Very often, a comprehensive set of performance data is not available and subjective measures can complement limited objective data (Ketokivi \& Schroeder, 2004). The scale can be used in full or in parts (selected dimensions) depending on the nature of each investigation. However, the selection of dimensions should carefully evaluate the most likely affected dimensions, as suggested by Ray et al. (2004). The scale can also be taken as a model for future expansion and refining with additional dimensions and indicators.

The conceptual contribution relates to the discussion of performance dimensionality. Our model clearly identifies at least five dimensions: financial performance, customer satisfaction, employee satisfaction, social performance and environmental performance. Multidimensionality implies indicators of different dimensions cannot be used interchangeably, since they represent different aspects of firm performance. Strategies may also have different impacts on each dimension.

The financial performance dimension as a second-order one, loading on profitability and growth, deserves further attention. This structure shows that using only profitability measures, as often happens, is an inadequate representation of financial performance, and can represent a serious flaw in empirical studies. Recent research defines competitive advantage as the ability to create more economic value than the marginal (break even) competitor in its product market (Peteraf \& Barney, 2003). Economic value is the wedge between the willingness to pay and the economic cost. If price is set below competitors' price, competitive advantage may manifest itself primarily in growth and not in profit. If price is set above competition the opposite would occur. Thus, measuring growth and profitability simultaneously seems conceptually justified.

The absence of a second-order construct affecting the non-financial dimensions is equally interesting. It suggests there is no common factor influencing the satisfaction of customers, employees, governments and communities. Indirectly, this result corroborates the remark of Fitzgerald and Storbeck (2003) that each stakeholder has its own agenda in relation to the company, since their satisfaction is associated to different firm actions. Prioritizing becomes an issue. Adopting the resource-dependence view, Frooman (1999) suggests a higher dependence on the stakeholders makes the relationship between stakeholder welfare and the company's outcomes stronger. As such, companies may need to focus on each group according to their relative importance and define specific strategies to please each group. Jensen (2001), reconciling the social and economic theories of the firm, puts the satisfaction of the different constituencies as a means to achieving market value maximization, the actual final goal of the company. This proposition implies managers can, and should, use this ultimate target to prioritize different stakeholders' needs and select appropriate strategies. It also adds a time perspective to the model by placing market value as the dependent variable in the long run, which could be explored in future research. 
This research certainly has limitations that could be explored in the future. The use of subjective indicators could have implications for the dimensional structure found. Rowe and Morrow (1999) however found a similar second-order financial construct using objective data, supporting our findings. The positive correlation between objective and subjective performance measures suggests this dimensional structure may hold for data collected with objective indicators. Secondly, the convenience and geographic characteristics of the sample do not allow generalization. In addition, the stakeholders that were considered to delimit the scope of the measurement model were the ones commonly mentioned by Brazilian companies, limiting the model to this country. The different constituencies' satisfaction was assessed in the view of high-level executives. They have access to objective data on firms' performance and are in a position to make a balanced judgment of the different demands of each stakeholder group. Yet they certainly do not fully represent all stakeholders. Another limitation links to reliability. Our results were valid and reliable, but reliability could be increased with the adoption of objective measures or multiple respondents, as suggest by Ketokivi and Schroeder (2004). Finally, market value was not tested as a possible dimension. Since market value is conceptually linked to financial performance (Combs et al., 2005) this is a point for future investigation.

\section{Received 28 June 2010; received in revised form 4 April 2011.}

\section{References}

Agle, B. R., Mitchell, R. K., \& Sonnenfeld, J. A. (1999). Who matter to CEOs? An investigation of stakeholder attributes and salience corporate performance, and CEO values. Academy of Management Journal, 42(5), 507-525. doi: 10.2307/256973

Barney, J., \& Clark, D. N. (2007). Resource-based theory. New York: Oxford.

Baum, J. R., \& Wally, S. (2003). Strategic decision speed and firm performance. Strategic Management Journal, 24(11), 1107-1129. doi: 10.1002/smj.343

Boyd, B. K., Gove, S., \& Hitt, M. A. (2005). Construct measurement in strategic management research: illusion or reality? Strategic Management Journal, 26(3), 239-257. doi: $10.1002 / \mathrm{smj} .444$

Brown, T. A. (2006). Confirmatory factor analysis for applied research. New York: The Guilford Press.

Cameron, K. (1986a). A study of organizational effectiveness and its predictors. Management Science, 32(1), 87-112. doi: $10.1287 / \mathrm{mnsc} .32 .1 .87$

Cameron, K. (1986b). Effectivineness as paradox: consensus and conflict in conceptions of organizational effectiveness. Management Science, 32(5), 539-553. doi: 10.1287/mnsc.32.5.539

Carneiro, J. (2005). Mensuração do desempenho organizacional: questões conceituais e metodológicas. In M. Gutierrez \& H. Bertrand (Eds.), Estudos em negócios IV (pp. 145-175). Rio de Janeiro: Mauad.

Carneiro, J. M. T., Silva, J. F., Rocha, A., \& Dib, L. A. R. (2007). Building a better measure of business performance. RAC-Eletrônica, 1(2), 114-135. Retrieved from http://www.anpad.org.br/periodicos/arq_pdf/a_639.pdf

Carton, R. B., \& Hofer, C. W. (2006). Measuring organizational performance: metrics for entrepreneurship and strategic management research. Cheltenham, UK; Northampton, MA: Edward Elgar. 
Chakravarthy, B. S. (1986). Measuring strategic performance. Strategic Management Journal, 7(5), 437-458. doi: 10.1002/smj.4250070505

Chen, I. J., Paulraj, A., \& Lado, A. A. (2004). Strategic purchasing, supply management, and firm performance. Journal of Operations Management, 22(5), 505-523. doi: 10.1016/j.jom.2004.06.002

Cho, H., \& Pucik, V. (2005). Relationship between innovativeness, quality, growth, profitability, and market value. Strategic Management Journal, 26(6), 555-575. doi: 10.1002/smj.461

Clarkson, M. B. E. (1995). A stakeholder framework for analyzing and evaluating corporate social performance. The Academy of Management Review, 20(1), 92-117. doi: 10.2307/258888

Combs, J. G., Crook, T. R., \& Shook, C. L. (2005). The dimension of organizational performance and its implications for strategic management research. In D. J. Ketchen \& D. D. Bergh (Eds.), Research methodology in strategy and management (pp. 259-286). San Diego: Elsevier.

Connolly, T., Conlon, E. J., \& Deutsch, S. J. (1980). Organizational effectiveness: a multipleconstituencies approach. Academy of Management Review, 5(2), 211-217. doi: 10.2307/257430

Crook, T. R., Ketchen, D. J., Jr., Combs, J. G., \& Todd, S. J. (2008). Strategic resources and performance: a meta-analysis. Strategic Management Journal, 29(11), 1141-1154. doi: $10.1002 / \mathrm{smj} .703$

Dawes, J. (1999). The relationship between subjective and objective company performance measures in market orientation research: further empirical evidence. Marketing Bulletin, 10(3), 65-75.

Dess, G. G., \& Robinson, R. B., Jr. (1984). Measuring organizational performance in the absence of objective measures: the case of the privately-held firm and conglomerate business unit. Strategic Management Journal, 5(3), 265-273. doi: 10.1002/smj.4250050306

Donaldson, T., \& Preston, L. E. (1995). The stakeholder theory of the corporation: concepts, evidence and implications. Academy of Management Review, 20(1), 65-91. doi:10.2307/258887

Fitzgerald, L., \& Storbeck, J. E. (2003). Pluralistic views of performance. Management Decision, 41(8), 741-750. doi: 10.1108/00251740310496251

Forker, L. B., Vickeky, S. K., \& Droge, C. L. M. (1996). The contribution of quality to business performance. International Journal of Operations and Production Management, 16(8), 44-62. doi: $10.1108 / 01443579610125778$

Fornell, C., Johnson, M. D., Anderson, E. W., Cha, J., \& Bryant, B. E. (1996). The American customer satisfaction index: nature, purpose and findings. Journal of Marketing, 60(4), 7-18. doi: $10.2307 / 1251898$

Fornell, C., \& Larcker, D. F. (1981). Evaluating structural equations models with unobservable variables and measurement error. Journal of Marketing Research, 18(1), 39-50. doi: $10.2307 / 3151312$

Freeman, R. E. (1984). Strategic management: a stakeholders approach. Boston: Pitman.

Frooman, J. (1999). Stakeholder influence strategies. The Academy of Management Review, 24(2), 191-205. doi: 10.2307/259074

Glick, W. H., Washburn, N. T., \& Miller, C. C. (2005, August). The myth of firm performance. Proceedings of the Annual Meeting of American Academy of Management. Honolulu, Hawaii. 
Hair, J. F., Anderson, R. E., Tatham, R. L., \& Black, W. C. (2005). Multivariate data analysis. New Jersey: Prentice-Hall.

Harter, J. K., Schmidt, F. L., \& Hayes, T. (2002). Business-unit-level relationship between employee satisfaction: a meta-analysis. Journal of Applied Psychology, 87(2), 268-279. doi: $10.1037 / / 0021-9010.87 .2 .268$

Hitt, M. A. (1988). The measuring of organizational effectiveness: multiple domains and constituencies. Management International Review, 28(2), 28-40.

Jensen, M. C. (2001). Value maximization, stakeholder theory, and the corporate objective function. Journal of Applied Corporate Finance, 14(3), 8-21. doi: 10.1111/j.1745-6622.2001.tb00434.x

Johnson, R. D. A., \& Greening, D. W. (1999). The effects of corporate governance and institutional ownership types on corporate social performance. Academy of Management Journal, 42(5), 564-576. doi:10.2307/256977

Kaplan, R. S., \& Norton, D. P. (1992). The balanced scorecard: measures that drive performance. Harvard Business Review, 70(1), 71-79.

Ketokivi, M. A., \& Schroeder, R. G. (2004). Perceptual measures of performance: fact or fiction? Journal of Operations Management, 22(3), 247-264. doi: 10.1016/j.jom.2002.07.001

Kim, H., Hoskisson, R. E., \& Wan, W. P. (2004). Power dependence, diversification strategy, and performance in keiretsu member firms. Strategic Management Journal, 25(7), 613-634. doi: $10.1002 / \mathrm{smj} .395$

Kline, R. B. (2005). Principles and practice of structural equation modeling (2nd ed.). New York: Guilford Press.

Krosnick, J. A. (1999). Survey research. Annual Review of Psychology, 50(1), 537-567. doi: 10.1146/annurev.psych.50.1.537

Mitchell, R. K., Agle, B. R., \& Wood, D. J. (1997). Toward a theory of stakeholder identification and salience: defining the principle of who and what really counts. Academy of Management Review, 22(4), 853-886. doi: 10.2307/259247

Mueller, R. O. (1996). Basic principles of structural equation modeling: an introduction to LISREL and EQS. New York: Springer.

Murphy, G. B., Trailer, J. W., \& Hill, R. C. (1996). Measuring performance in entrepreneurship research: an empirical review of the literature. Journal of Business Research, 36(1), 15-23. doi: 10.1016/0148-2963(95)00159-X

Neely, A. (2007). Business performance measurement (2nd ed.). Cambridge: Cambridge University Press.

Netemeyer, R. G., Bearden, W. O., \& Sharma, S. (2003). Scaling procedures: issues and applications. London: Sage Publications.

Pedhazur, E. J., \& Schmelkim, L. (1991). Design and analysis: an integrated approach. Hillsdale: Lawrence Erlbaum Associates Publishers.

Peteraf, M. A., \& Barney, J. B. (2003). Unraveling the resource-based tangle. Managerial and Decision Economics, 24(4), 309-323. doi: 10.1002/mde.1126 
Ray, G., Barney, J. B., \& Muhanna, W. A. (2004). Capabilities, business processes, and competitive advantage: choosing the dependent variable in empirical tests of the resource-based view. Strategic Management Journal, 25(1), 23-37. doi: 10.1002/smj.366

Richard, P. J., Devinney, T. M., Yip, G. S., \& Johnson, G. (2009). Measuring organizational performance: towards methodological best practice. Journal of Management, 35(3), 718-804. doi: $10.1177 / 0149206308330560$

Rowe, W. G., \& Morrow, J. L., Jr. (1999). A note on the dimensionality of the firm financial performance construct using accounting, market, and subjective measures. Canadian Journal of Administrative Sciences, 16(1), 58-70. doi: 10.1111/j.1936-4490.1999.tb00188.x

Rumelt, R. P., Schendel, D. E., \& Teece, D. J. (1994). Fundamental issues in strategy. In R. P. Rumelt, D. E. Schendel, \& D. J. Teece (Eds.), Fundamental issues in strategy (pp. 9-54). Boston: Harvard Business School Press.

Seashore, S. E., \& Yuchtman, E. (1967). Factorial analysis of organizational performance. Administrative Science Quarterly, 12(3), 377-395. doi: 10.2307/2391311

Shah, R., \& Goldstein, S. M. (2006). Use of structural equations modeling in operations management research: looking back and forward. Journal of Operations Management, 24(2), 148-169. doi: 10.1016/j.jom.2005.05.001

Shook, C. L., Ketchen, D. J., Hult, T. G., \& Kacmar, K. M. (2004). An assessment of the use of structural equation modeling in strategic management research. Strategic Management Journal, 25(4), 397-404. doi: 10.1002/smj.385

Sila, I. (2007). Examining the effects of contextual factor on TQM and performance through the lens of organizational theories: an empirical study. Journal of Operations Management, 25(1), 83109. doi: 10.1016/j.jom.2006.02.003

Sila, I., \& Ebrahimpour, M. (2005). Critical linkages among TQM factors and business results. International Journal of Operations and Production Management, 25(11), 1123-1155. doi: $10.1108 / 01443570510626925$

Silverman, B. S., Nickerson, J. A., \& Freeman, J. (1997). Profitability, transactional alignment, and organizational mortality in the U.S. trucking industry [Special Issue]. Strategic Management Journal, 18, 31-52. doi: 10.1002/(SICI)1097-0266(199707)18:1+<31::AID-SMJ920>3.0.CO;2-S

Simerly, R. L., \& Li, M. (2000). Environmental dynamism, capital structure and performance: a theoretical integration and an empirical test. Strategic Management Journal, 21(1), 31-49. doi: 10.1002/(SICI)1097-0266(200001)21:1<31::AID-SMJ76>3.0.CO;2-T

Slater, S. F., \& Olson, E. M. (2000). Strategy type and performance: the influence of sales force management. Strategic Management Journal, 21(8), 813-829. doi: 10.1002/10970266(200008)21:8<813::AID-SMJ122>3.0.CO;2-G

Steers, R. M. (1975). Problems in the measuring of organizational effectiveness. Administrative Science Quarterly, 20(4), 546-558. doi: 10.2307/2392022

Venkatraman, N., \& Grant, J. (1986). Construct measurement in organizational strategy research: a critique and proposal. Academy of Management Review, 11(1), 71-87. doi: 10.2307/258332

Venkatraman, N., \& Ramanujam, V. (1986). Measurement of business performance in strategy research: a comparison of approaches. Academy of Management Review, 1(4), 801-814. doi: $10.2307 / 258398$ 
Venkatraman, N., \& Ramanujam, V. (1987). Measurement of business economic performance: an examination of method convergent. Journal of Management, 13(1), 109-122. doi: $10.1177 / 014920638701300109$

Waddock, S. A., \& Graves, S. B. (1997a). Quality of management and quality of stakeholder relations. Business and Society, 36(3), 250-279. doi: 10.1177/000765039703600303

Waddock, S. A., \& Graves, S. B. (1997b). The corporate social performance-financial performance link. Strategic Management Journal, 18(4), 303-319. doi: 10.1002/(SICI)10970266(199704)18:4<303::AID-SMJ869>3.0.CO;2-G

Wall, T. D., Michie, J., Patterson, M., Wood, S. J., Sheeran, M., Clegg, C. H., \& West, M. (2004). On the validity of subjective measures of company performance. Personnel Psychology, 57(1), 95118. doi: 10.1111/j.1744-6570.2004.tb02485.x

Whetten, D. A. (1987). Organizational growth and decline process. Annual Review of Sociology, 13(1), 335-358. doi: 10.1146/annurev.so.13.080187.002003

Wiklund, J., \& Shepherd, D. (2003). Knowledge-based resources, entrepreneurial orientation, and the performance of small and medium-sized businesses. Strategic Management Journal, 24(13), 1307-1314. doi: $10.1002 / \mathrm{smj} .360$

Zammuto, R. F. (1984). A comparison of multiple constituency models of organizational effectiveness. Academy of Management Review, 9(4), 606-616. doi:10.2307/258484 